\title{
Four viral proteins of white spot syndrome virus (WSSV) that attach to shrimp cell membranes
}

\author{
Yan Liang ${ }^{1,2,3}$, Jie Huang ${ }^{1,2, *}$, Xiao-Ling Song ${ }^{1}$, Pei-Jun Zhang ${ }^{2}$, Huai-Su Xu ${ }^{4}$ \\ ${ }^{1}$ Key Laboratory of Experimental Marine Biology, Institute of Oceanology, Chinese Academy of Sciences, Qingdao 266071, \\ PR China \\ ${ }^{2}$ Yellow Sea Fisheries Research Institute, Chinese Academy of Fishery Sciences, Key Laboratory for Sustainable Utilization \\ of Marine Fisheries Resources, Ministry of Agriculture, Qingdao 266071, PR China \\ ${ }^{3}$ Graduate School, Chinese Academy of Sciences, Beijing 100039, PR China \\ ${ }^{4}$ Ocean University of China, Qingdao 266003, PR China
}

\begin{abstract}
White spot syndrome virus (WSSV) is a major shrimp pathogen that has a widespread negative affect on shrimp production in Asia and the Americas. It is known that WSSV infects shrimp cells through viral attachment proteins (VAP) that bind with shrimp cell receptors. However, the identity of both WSSV VAP and shrimp cell receptors remains unclear. We used digoxigenin (DIG)labeled shrimp hemocyte and gill cell membranes to bind to WSSV proteins immobilized on nitrocellulose membranes, and 4 putative WSSV VAP (37 kDa, $39 \mathrm{kDa}$ and 2 above $97 \mathrm{kDa})$ were identified. Mass spectrometric analysis identified the $37 \mathrm{kDa}$ putative VAP as the product of WSSV gene VP281.
\end{abstract}

KEY WORDS: Viral attachment protein · White spot syndrome virus · WSSV · Shrimp • VP28 Resale or republication not permitted without written consent of the publisher

\section{INTRODUCTION}

White spot syndrome virus (WSSV) is the causative agent of a deadly disease of cultured penaeid shrimp. It is an enveloped, double stranded DNA virus that is rod-shaped and 70 to 150 by 250 to $380 \mathrm{~nm}$ in size. Its complete genome sequence has already been reported (van Hulten et al. 2001a, Yang et al. 2001). Although WSSV has some characteristics similar to nonoccluded baculoviruses, it was designated unclassified in 1995 (van Hulten et al. 2000a) and later placed in a new genus, Whispovirus, and family, Nimaviridae (Mayo 2002) (http://www.ncbi.nlm.nih.gov/ICTVdb/ Ictv/index.htm). The viral particle contains at least 5 major proteins with estimated sizes of $28 \mathrm{kDa}$ (VP28), $26 \mathrm{kDa}$ (VP26), $24 \mathrm{kDa}$ (VP24), $19 \mathrm{kDa}$ (VP19) and 15kDa (VP15) (van Hulten et al. 2001b), and amongst these, 6 envelope proteins (VP28, VP26, VP22, VP19, VP466 and VP281) have been identified (van Hulten et al. 2000b, Huang et al. 2002a,b).
WSSV infections are systemic and characterized by rapid replication in various tissues, including the hypoderm, hematopoietic tissue, antennal gland and hemocytes not only of shrimp but also of other crustaceans (Huang et al. 1995b, Lightner 1996, Lo et al. 1997, Lei et al. 2002). WSSV can be inactivated by treatment at $56^{\circ} \mathrm{C}$ for $30 \mathrm{~min}$, with ether (Huang et al. 1995a), or by treatment at $70^{\circ} \mathrm{C}$ for $5 \mathrm{~min}, \mathrm{pH} 5.0,2 \% \mathrm{NP} 40$, or $1 \%$ Triton X-100 (Xie et al. 2000).

The interaction of any virus with its host's cellular receptors initiates a chain of dynamic events that enable entry of the virus into the host cell. The capability of viral attachment proteins (VAP) to bind to these specific cellular receptors is the basis of cell and tissue tropism (Schneider-Schaulies 2000). Evidence from bioassays, histopathology, ELISA with monoclonal antibodies, gene probes and PCR have shown that WSSV can infect a wide range of crustacean hosts including different genera of penaeid shrimp, Alpheus spp., Callianassa spp., Exopalaemon 
spp., Balanus spp., Helice spp., Ephydridae spp., copepods, and Procambarus spp. (Huang et al. 1995c, Lo et al. 1996, Lei et al. 2002). These facts suggest that WSSV has VAP that can bind to common targets on different cells in a variety of hosts. However, the mechanisms for WSSV entry into shrimp cells and for the development of systemic infections are still unknown.

van Hulten et al. (2001b) reported that intramuscular injection of antiserum against WSSV major envelope protein VP28 was able to neutralize WSSV infection of Penaeus monodon in a concentration-dependent manner. Namikoshi et al. (2004) confirmed by bioassay that both rabbit anti-rVP26 and anti-rVP28 sera could neutralize WSSV, and they proposed that both VP26 and VP28 were 'protective antigens' that could evoke protection of shrimp by vaccination. In this paper we provide evidence that $4 \mathrm{WSSV}$ envelope proteins other than VP26 and VP28 may be VAP.

\section{MATERIALS AND METHODS}

Virus source. WSSV (Sample No. WSSV-990901) was isolated from the gills of diseased shrimp suffering from white spot syndrome (WSS) at a local farm in Jiaonan City of Qingdao, Shandong Province, China, in September 1999. The gills of the diseased shrimp were removed from the cephalothorax and were kept frozen at $-75^{\circ} \mathrm{C}$.

Animals. Wild penaeid shrimp Fenneropenaeus chinensis, 17 to $20 \mathrm{~cm}$ in body length, were caught from the sea near Qingdao in May 2001 and held in 2001 indoor tanks containing seawater for $2 \mathrm{wk}$ at $20^{\circ} \mathrm{C}$. PCR was conducted to select WSSV and HPV (hepatopancreatic parvo-like virus)-free individuals for the preparation of cell membrane protein.

WSSV purification. About $10 \mathrm{~g}$ of gills from diseased shrimp was homogenized in $10 \mathrm{ml}$ cold modified high-osmolarity phosphate-buffered saline (HOPBS) containing: $\mathrm{NaCl}, 288.8 \mathrm{mmol} \mathrm{l}^{-1}$; $\mathrm{KCl}, 2.7$ mmol l-1; $\mathrm{Na}_{2} \mathrm{HPO}_{4}, 4.3 \mathrm{mmol} \mathrm{l}{ }^{-1} ; \mathrm{KH}_{2} \mathrm{PO}_{4}, 1.4 \mathrm{mmol}$ $\mathrm{l}^{-1}$; pH 7.3; osmolarity at $600 \mathrm{mOsmol} \mathrm{l}^{-1}$ ). The homogenate was centrifuged at $500 \times g$ for $20 \mathrm{~min}$ at $4^{\circ} \mathrm{C}$ to pellet cellular debris. The resulting supernatant was further centrifuged twice at $3000 \times g$ for $20 \mathrm{~min}$ at $4^{\circ} \mathrm{C}$. Sucrose was added to the supernatant to a final concentration of $30 \%(w / w)$. The sucroserich supernatant was then centrifuged at $70000 \times g$ for $1.5 \mathrm{~h}$ at $4^{\circ} \mathrm{C}$. The virus pellet was removed and resuspended in about $3 \mathrm{ml}$ HOPBS. It was layered on top of a 33 to $62 \%$ (w/w, in HOPBS) sucrose gradient and centrifuged at $153200 \times g$ for $3 \mathrm{~h}$ at $4^{\circ} \mathrm{C}$. The viral band (46 and $47 \%$ sucrose w/w) was collected and dialyzed against HOPBS to remove sucrose and stored in $100 \mu \mathrm{l}$ aliquots at $-75^{\circ} \mathrm{C}$ for future use. The amount of viral protein was measured using the Bradford method (Smith 1995).

Preparation of digoxigenin (DIG)-labeled total cell membrane protein. Shrimp hemolymph preserved in $3.8 \%$ sodium citrate was centrifuged at $600 \times g$ for $10 \mathrm{~min}$ at $4^{\circ} \mathrm{C}$ and homogenized in a Dounce homogenizer in 5 times volume of ice-cold RSB-NP40 containing: $\mathrm{MgCl}_{2}, 1.5 \mathrm{mmol} \mathrm{l}^{-1}$; Tris- $\mathrm{HCl}, 10 \mathrm{mmol} \mathrm{l}^{-1}$; $\mathrm{NaCl}$, $10 \mathrm{mmol} \mathrm{l}^{-1}$; NP-40, 1\%; EDTA, $2 \mathrm{mmol} \mathrm{l}^{-1}$; and $0.5 \mathrm{mmol} \mathrm{l}^{-1}$ phenylmethylsulfonyl fluoride (PMSF); $0.7 \mu \mathrm{g} \mathrm{ml}^{-1}$ pepstatin; leupeptin to $5 \mu \mathrm{g} \mathrm{ml} \mathrm{m}^{-1}$; and $5 \mu \mathrm{g} \mathrm{ml}^{-1}$ chymostatin, all of which were freshly added. Gill tissue was homogenized in another Dounce homogenizer with 5 times volume of ice-cold RSB-NP40. After centrifugation at 600 and $800 \times g$ for $10 \mathrm{~min}$ to remove nuclei, debris, and chromosomes, the membrane components in the supernatant were pelleted by centrifuging at $100000 \times g$ for $20 \mathrm{~min}$ at $4^{\circ} \mathrm{C}$. The pellet was resuspended in $100 \mu \mathrm{l}$ of HOPBS and incubated with $32 \mu$ DIG-NHS (digoxigenin-3-O-methylcarbonyl- $\epsilon$-aminocaproicacid-N-hydroxysuccinimide ester) for $2 \mathrm{~h}$ at room temperature. DIG-labeled membrane components were isolated from the reaction mixture through a Sephedax G25 column. The resulting suspension was measured for protein concentration using the Bradford method (Smith 1987) and stored at $-75^{\circ} \mathrm{C}$ in $50 \mu$ l aliquots.

Western blot assay. Western blotting was carried out on WSSV membrane to identify virus polypeptides involved in virus-cell binding. The polypeptide bands of sodium dodecyl sulphate polyacrylamide gel electrophoresis (SDS-PAGE) of $300 \mu \mathrm{g}$ WSSV protein were transferred to 2 nitrocellulose membranes and fixed by heating at $80^{\circ} \mathrm{C}$ for $1 \mathrm{~h}$. The membranes were blocked in Buffer II at $37^{\circ} \mathrm{C}$ for $30 \mathrm{~min}$ and then washed 3 times with HOPBS. One of the membranes was incubated with DIG-labeled hemocyte membrane protein at $4^{\circ} \mathrm{C}$ overnight; another membrane was incubated with DIG-labeled grill membrane protein at $4^{\circ} \mathrm{C}$ overnight. Color development on the membranes was performed as described above.

Elution of WSSV VP37 and mass spectrometry analysis. Purified WSSV virions were separated using $12 \%$ SDS-PAGE in a special $2 \mathrm{~mm}$ gel. GelCode EZinc $^{\mathrm{TM}}$ Reversible Stain Kit (Pierce) was used for rapid detection of protein bands. The target protein, VP37, was visualized and excised when the negative stained gel was placed against a black background. E-Zinc ${ }^{\mathrm{TM}}$ eraser solution was used to eliminate protein dye contamination before apparatus elution (Model 422, BioRad) in buffer (50 mM NH $\left.\mathrm{HCO}_{3}, 0.1 \% \mathrm{SDS}\right)$. This eluted VP37 was used for both Western blot analysis and mass spectrometry analysis (Fudan University, Shanghai, China). 


\section{RESULTS}

\section{Western blotting}

Polypeptides associated with binding activity were identified by Western blotting. Nitrocellulose membranes were blotted from $12 \%$ SDS-PAGE of WSSV structural polypeptides (Fig. 1A) and incubated with DIG-labeled cellular membrane proteins of both gills and hemocytes, allowing adsorption to putative VAP. After application of alkaline phosphatase (AP)conjugated anti-DIG antibody and subsequent color development, 4 bands appeared. Two were above $97 \mathrm{kDa}$ and another 2 were 37 and $39 \mathrm{kDa}$, respectively (Fig. 1B). These 4 proteins were considered to be candidate VAPs of WSSV.

\section{Further identification of WSSV VP37}

The nitrocellulose membrane with target proteins was stained with ponceau S (Fig. 2A) before probing with DIG-labeled membrane proteins of shrimp, to show the eluted VP37 and the polypeptides of WSSV after SDS-PAGE. It should be noted that the 2 VAP
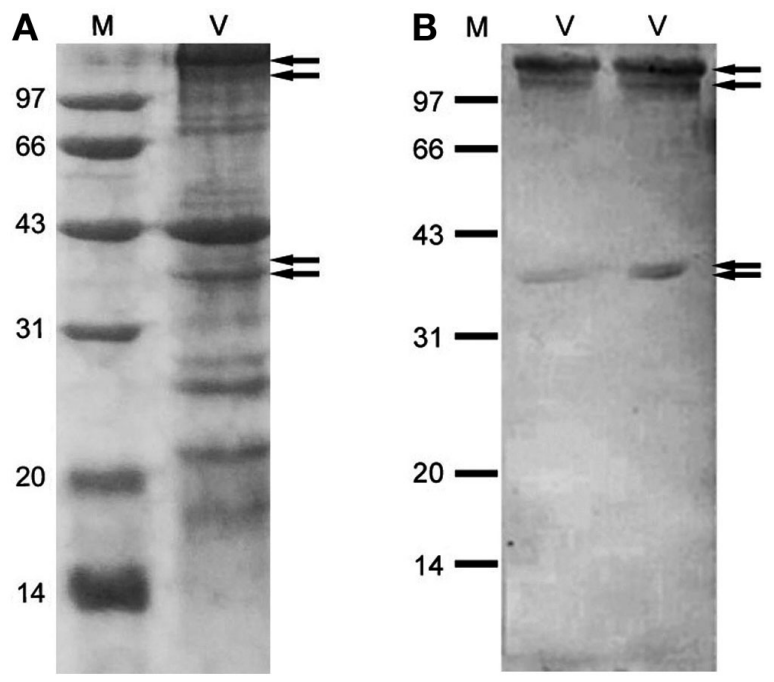

Fig. 1. Western blot of nitrocellulose membrane after sodium dodecyl sulphate polyacrylamide gel electrophoresis (SDSPAGE) of white spot syndrome virus (WSSV) structural polypeptides. (A) Coomassie brilliant blue G250-stained SDSPAGE of WSSV structural polypeptides. Arrows show the protein bands corresponding to those on the blotted membrane. (B) After digoxigenin (DIG)-labeled cellular membrane proteins were bound to the nitrocellulose membrane containing blotted viral structural polypeptides, 4 bands (indicated by arrows) were revealed by AP-conjugated DIG antibody. Lane M: low molecular weight protein marker (Roche, Cat. No. V5235S, German); Lane V: WSSV purified from diseased shrimp Fenneropenaeus chinensis
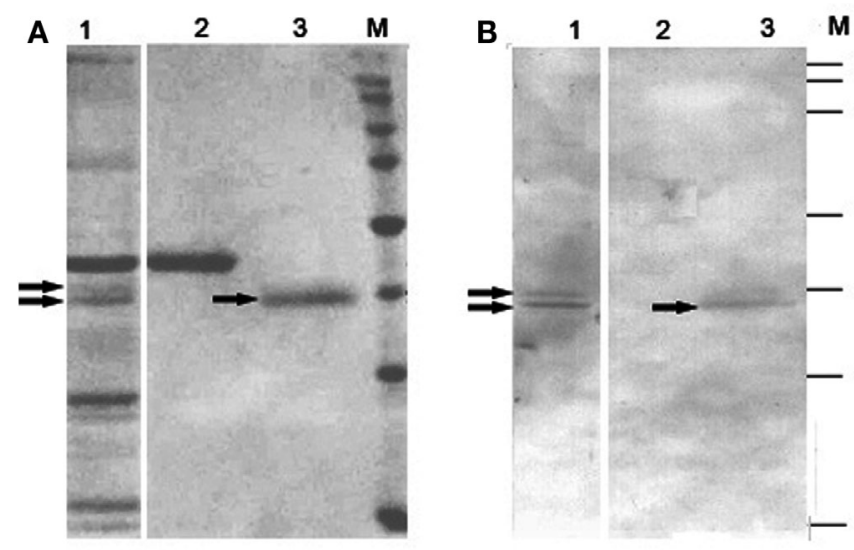

Fig. 2. Binding assay of eluted VP37. (A) A nitrocellulose blot of SDS-PAGE separated WSSV viral proteins stained with ponceau S. Arrows show the corresponding proteins VP39 and VP37 of WSSV. (B) The same membrane probed with a DIG-labeled membrane preparation and visualized using horseradish peroxidase (HRP)-conjugated anti-DIG antibody. Arrows show viral attachment proteins of WSSV. Lane 1: WSSV purified from diseased shrimp Fenneropenaeus chinensis; Lane 2: $43 \mathrm{kDa}$ protein from WSSV as a negative control; Lane 3: VP37 obtained by electro-elution; Lane 4: low molecular weight marker (Roche)

above $97 \mathrm{kDa}$ were lost due to the low efficiency of transfer. After Western blot analysis, clear bands appeared on the membrane, verifying the binding capacity of both VP37 and eluted VP37 (Fig. 2B).

Mass spectrometry analysis of WSSV VP37 was conducted and the amino sequence of VP37 was identified (Fig. 3). It was shown that WSSV VP37 belonged to the group of WSSV envelope proteins and had the cell attachment motif of 'Arg-Gly-Asp'. A WSSV ORF (open reading frame) database search identified VP37 as the product of gene VP281.

\section{DISCUSSION}

Four putative VAPs of WSSV were identified. The 2 above $97 \mathrm{kDa}$ (high molecular weight [MW] VAP) may be combinatorial proteins that contain complexes of the low MW VAP or the high MW proteins and low MW proteins may be completely independent polypeptides. However, recent studies from our laboratory show that antibodies to the low MW VAP do not cross-react with the high MW VAP (P. Q. Jia unpubl.), suggesting that WSSV has 4 VAP proteins involved in attachment to host cell receptors.

VP37 contained the cell attachment sequence, Arg-Gly-Asp (RGD motif, PROSITE accession number PS00016) and might be produced in a soluble form since gene VP281 lacks a prominant transmembrane 


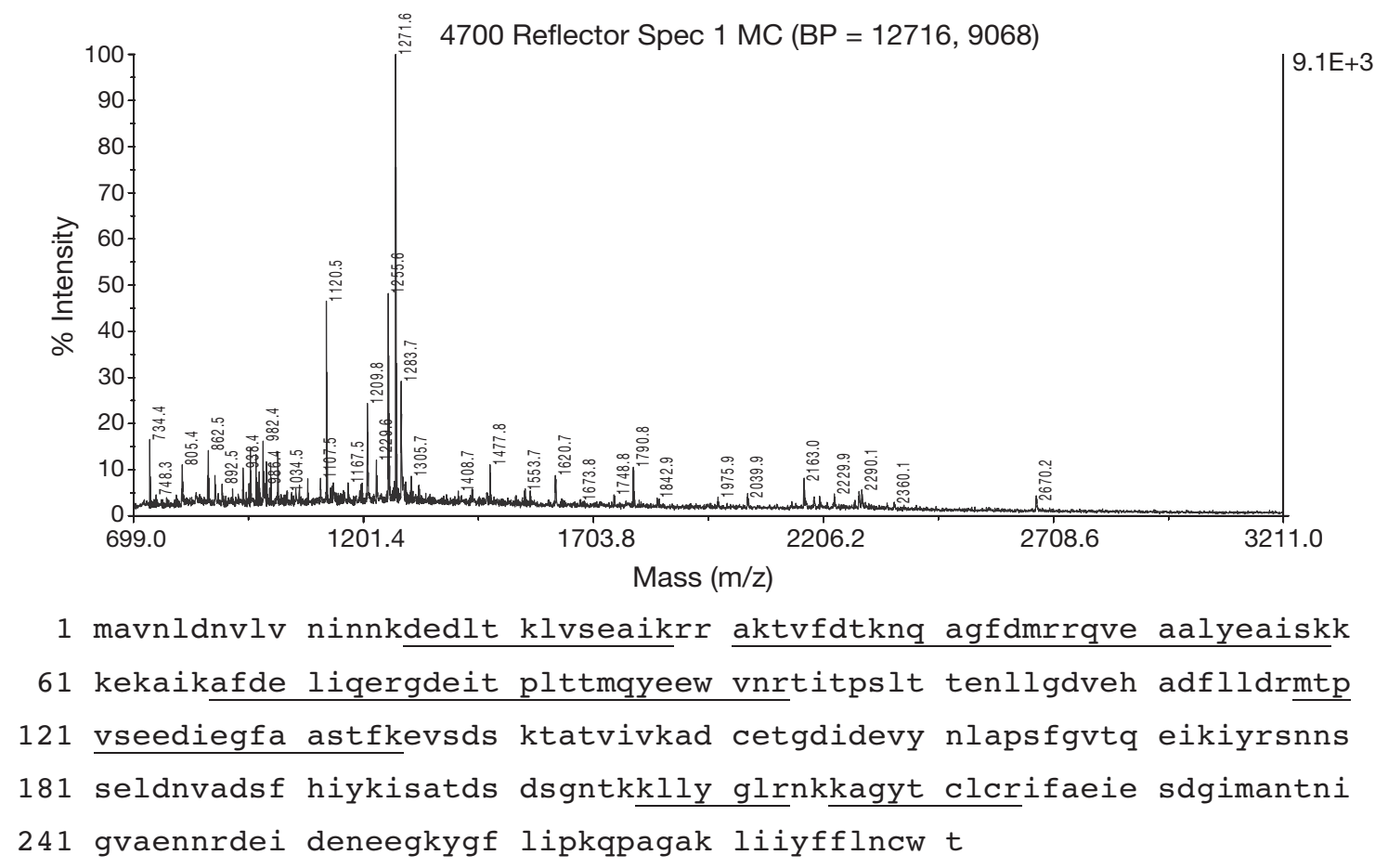

Fig. 3. Mass spectrometry fragments of VP37 obtained by MOLDI-TOF spectrometry (MS+MS/MS, mass spectrum) and compared to the deduced amino acid sequence of gene VP281 from GenBank. Peptide fragments that match the VP281 sequence are indicated by underlines

region (Huang et al. 2002a). These structural characteristics indicate that VP281 might play an important role in initiating WSSV infection by helping to anchor WSSV to its host.

The only aquatic animal virus for which a virus cellular receptor has been reported is fish rhabdovirus VHSV (viral hemorrhagic septicemia virus) (Bearzotti et al. 1999). However, no VAP has been identified from this virus. Thus, the present study is the first to identify the VAP of an aquatic animal virus. As VAPs are associated with host cellular receptors and may be involved in host resistance to infection, study of WSSV VAPs and their receptors is of great interest. Since WSSV VP37 is involved in WSSV infection, it is possible that it may be further developed for use in preventing or inhibiting WSSV infection in shrimp.

Acknowledgements. This work was funded by projects under the Major State Basic Research Development Program (Grant G1999012002), the National Nature Science Foundation of China (Grant 30271020), and the Natural Science Foundation of Shandong Province (Grant Q2002D02), as well as the Foundation of the Chinese Academy of Fishery Sciences (Grant 2003-Qing-6), the National Nature Science Foundation of Qingdao (Grant 03-2-JZP-10), and the Chinese Ministry of Agriculture Key Laboratory for Sustainable Utilization of Marine Fisheries Resources (Grant 2004-06).

\section{LITERATURE CITED}

Bearzotti M, Delmas B, Lamoureux A, Loustau AM, Chilmonczyk S, Bremont M (1999) Fish rhabdovirus cell entry is mediated by fibronectin. J Virol 73:7703 - 7709

Huang C, Zhang X, Lin Q, Xu X, Hew CL (2002a) Characterization of a novel envelope protein (VP281) of shrimp white spot syndrome virus by mass spectrometry. J Gen Virol 83:2385-2392

Huang C, Zhang X, Lin Q, Xu X, Hu Z, Hew CL (2002b) Proteomic analysis of shrimp white spot syndrome viral proteins and characterization of a novel envelope protein VP466. Mol Cell Proteomics 1:223-231

Huang J, Cai SL, Song XL, Wang CM, Yu J, Yang CH (1995a) Study on artifical infection for Penaeus chinensis by the pathogen of the explosive epidemic disease of shrimp. Mar Fish Res 16(1):51-58

Huang J, Song XL, Yu J, Yang CH (1995b) Baculoviral hypodermal and hematopoietic necrosis-study on the pathogen and pathology of the explosive epidemic disease of shrimp. Mar Fish Res 16(1):1-6

Huang, J, Yu J, Song XL, Yang CH (1995c) Primary investigation on the viral pathogens and transmission route during the explosive epidemic shrimp disease in Zhejiang in 1994. Mar Fish Res 16(1):91-98

Lei ZW, Huang J, Shi CY, Zhang LJ, Yu KK (2002) Investigation into the hosts of White Spot Syndrome Virus (WSSV). Oceanol Limnol Sin 33:250-258

Lightner DV (1996) A handbook of shrimp pathology and diagnostic procedures for diseases of cultured penaeid shrimp. World Aquaculture Society, Baton Rouge, LA

Lo CF, Ho CH, Peng SE, Chen CH and 7 others (1996). White spot syndrome baculovirus (WSBV) detected in cultured 
and captured shrimp, crabs and other arthropods. Dis Aquat Org 27:215-225

Lo CF, Ho CH, Chen CH, Liu KF and 9 others (1997) Detection and tissue tropism of white spot syndrome baculovirus (WSBV) in captured brooders of Penaeus monodon with a special emphasis on reproductive organs. Dis Aquat Org 30:53-72

Mayo MA (2002) A summary of taxonomic changes recently approved by ICTV. Arch Virol 147:1655-1656

Namikoshi A, Wu JL, Yamashita T, Nishizawa T, Nishioka T, Arimoto M, Muroga K (2004) Vaccination trials with Penaeus japonicus to induce resistance to white spot syndrome virus. Aquaculture 229:25-35

Schneider-Schaulies J (2000) Cellular receptors for viruses: links to tropism and pathogenesis. J Gen Virol 81: 1413-1429

Smith JA (1995) Quantitation of proteins. In: Ausubel FM, Brent R, Kingston RE, Moore DD and 7 others (eds) Current protocols in molecular biology. John Wiley \& Sons, New York, p 10.1.1-10.1.3

Editorial responsibility: Timothy Flegel, Bangkok, Thailand van Hulten MCW, Tsai MF, Schipper CA, Lou CF, Kou GH, Vlak JM (2000a) Analysis of a genomic segment of white spot syndrome virus of shrimp containing ribonucleotide reductase genes and repeat regions. J Gen Virol 81:307-316 van Hulten MCW, Westenberg M, Goodall SD, Valk JM (2000b) Identification of two major virion protein genes of white spot syndrome virus of shrimp. Virology 266:227-236

van Hulten MCW, Witteveldt J, Peters S, Kloosterboer N and 5 others (2001a) The white spot syndrome virus DNA genome sequence. Virology 286:7-22

van Hulten MCW, Witteveldt J, Snippe M, Vlak JM (2001b) White spot syndrome virus envelope protein VP28 is involved in the systemic infection of shrimp. Virology 285: 228-233

Xie ST, Qiu DQ, He JG, Yang XM, Jiang JB (2000). Effect of several physical and chemical factors on viability of white spot baculovirus of Penaeus monodon. Mar Sci 24:52-54

Yang F, He J, Lin X, Li Q, Pan D, Zhang X, Xu X (2001) Complete genome sequence of the shrimp white spot bacilliform virus. J Virol 75:11811-11820

Submitted: August 8, 2004; Accepted: March 17, 2005

Proofs received from author(s): July 25, 2005 